\title{
Interspecific variation in the allelopathic potential of the family Myrtaceae
}

\author{
Maristela Imatomi ${ }^{1}$, Paula Novaes ${ }^{2}$ and Sonia Cristina Juliano Gualtieri ${ }^{1}$
}

Submitted: 14 August, 2012. Accepted: 10 October, 2012

\begin{abstract}
Allelopathy is a type of biotic interference wherein a plant releases bioactive metabolites into an environment, thereby affecting the adjacent biota. Stressful environments stimulate the production of these metabolites. The present study tests the novel weapons hypothesis, which postulates that species belonging to the same genus and from the same environment have similar allelopathic effects. The aim of this study was to assess the allelopathic effects that the aqueous leaf extracts of 15 species belonging to five genera of the Myrtaceae family have on the seed germination and initial seedling growth of lettuce (Lactuca sativa L.), tomato (Solanum lycopersicum L.) and onion (Allium cepa L.). Germination rates, average germination times, informational entropy of germination and allelopathic effects, as quantified with a response index, were calculated. A taxonomic distance matrix based on Gower dissimilarity and a Euclidean distance matrix were constructed. The results revealed that all extracts from donor species significantly increased average germination time or reduced the germination rate of eudicotyledonous plant species. The only extracts that showed no effect on monocotyledonous seeds were those of Campomanesia pubescens O. Berg and Psidium cinereum Mart. We conclude that eudicotyledonous and monocotyledonous plants were both significantly affected by the presence of all extracts tested. Our results make it clear that each species behaves distinctly in relation to allelopathic activity, with no apparent grouping by genus or subtribe. Therefore, the hypothesis was rejected, because plants from the same environment and with taxonomic proximity do not necessarily display similar production of secondary metabolites.
\end{abstract}

Key words: Allelopathy, Aqueous leaf extract, Genus similarity, Germination

\section{Introduction}

In the neotropical savanna of Brazil (the cerrado), plants grow in nutrient-poor soils (Haridasan 2008). Therefore, the replacement of predated leaves represents a high cost (Fine et al. 2006) and competition for nutrients is intense. Consequently, plant species in this ecosystem have developed defense mechanisms, such as the production of leaves only in propitious periods; the production of coriaceous leaves; the lowering of nitrogen and water content; and the elevation of quantities of phenolic compounds (Marquis et al. 2002). Predation and competition for natural resources restrict the distribution of plants, acting as an environmental filter by selecting species with similar traits that allow their survival under environmentally challenging conditions (Fukami et al. 2005). Thus, functional traits are generally phylogenetically conserved in plant lineages (Ackerly 2003). Therefore, phylogenetic proximity among species and traits inherited from a common ancestry should correlate with similar responses to environmental processes (Webb et al. 2002; Núñez-Farfán et al. 2007). The novel weapons hypothesis postulates that plant species belonging to the same genus and subjected to the same environmental conditions tend to have similar characteristics, principally with respect to their defense mechanisms, which include the production of inhibitory secondary metabolic compounds. To test this hypothesis, we collected samples of 15 species belonging to five genera of the family Myrtaceae, all from the cerrado ecosystem. Our objective was to determine whether the allelopathic effect is similar across the genera.

Allelopathy is a type of biotic interference wherein a plant releases bioactive metabolites, known as allelochemicals, into the surrounding environment. The growth of neighboring vegetation might be affected and a selective advantage thus afforded the donor plant (Anaya 1999). Allelochemicals affect various metabolic processes in or-

\footnotetext{
${ }^{1}$ Universidade Federal de São Carlos, Departamento de Botânica, São Carlos, SP, Brazil

${ }^{2}$ Universidad de Cádiz, Departamento de Química Orgánica, Grupo de Alelopatia, Puerto Real, Cádiz, Spain

${ }^{3}$ Author for correspondence: maristelaimatomi@yahoo.com.br
} 
ganisms: altering membrane permeability (Bogatek et al. 2005) and ion absorption (Gniazdowska \& Bogatek 2005); inhibiting electron transport in photosynthesis and respiration (Abrahim et al. 2000); changing enzyme activity (Singh et al. 2009); and impeding cell division (Teerarak et al. 2010). Because of these effects, allelopathy is recognized as an important ecophysiological process in ecosystems, influencing primary and secondary plant succession, as well as the structure, composition and dynamics of native or cultivated plant communities (Rizvi et al. 1992; Scrivanti et al. 2003). In addition, allelopathy plays a key role in the detection of bioactive compounds of commercial importance (Oliveros-Bastidas 2008).

Worldwide, the family Myrtaceae includes approximately 3,100 species in approximately 140 genera, divided into two subfamilies, Leptospermoideae and Myrtoideae, outlined in the second edition of the Angiosperm Phylogeny Group classification system, as modified by Judd et al. (1999) and later ratified by Watson \& Dallwitz (2007). In Brazil, the subfamily Myrtoideae comprises 23 genera and approximately 1,000 species (Cardoso \& Sajo 2006). The floral inventory compiled by the Brazilian Institute of Geography and Statistics showed that the cerrado contains approximately 211 Myrtaceae species in 14 genera, making this family one of the most representative in the ecosystem. Species of Eucalyptus (subfamily Leptospermoideae), the most widely studied genus in the family Myrtaceae, have been reported to show allelopathic effects (Fang et al. 2009). However, there have been few studies of the allelopathic potential of Myrtaceae species found in the cerrado ecosystem, most of which belong to the subfamily Myrtoideae. In the cerrado, some Myrtaceae species have been observed to inhibit the growth of adjacent plants, indicating that the former produce allelochemicals. Therefore, the aim of this study was to assess the allelopathic effects that the aqueous leaf extracts of 15 species belonging to five Myrtaceae family genera found in the cerrado ecosystem have on the seed germination and initial seedling growth of Lactuca sativa (lettuce), Solanum lycopersicum (tomato) and Allium cepa (onion).

\section{Materials and methods}

\section{Collection area}

The plant material used in this study was collected in the cerrado (stricto sensu) in the state of São Paulo, Brazil $\left(21^{\circ} 58^{\prime}\right.$ to $22^{\circ} 00^{\prime} \mathrm{S} ; 47^{\circ} 51^{\prime}$ to $\left.47^{\circ} 52^{\prime} \mathrm{W}\right)$. According to the Köppen climate classification system, the climate in the region is type Cwa, with two well-defined seasons (Monteiro \& Prado 2006): a wet season (from October through March) and a dry season (from April through September). The vegetation is characterized by a woody layer composed of trees and bushes that protrude above a clearly defined herbaceous layer (Ribeiro \& Walter 1998).

\section{Biological material}

The Myrtaceae specimens found on-site were marked and observed until the period of flowering and fruiting, enabling the species to be identified. The leaves of each species were non-systematically collected from at least five plants in the vegetative stage, during the dry season. Leaves were collected from the following donor species (all belonging to the tribe Myrteae): subtribe Myrtinae-Blepharocalyx salicifolius Kuth O. Berg, Campomanesia pubescens O. Berg, Psidium australe Cambess., P. cinereum Mart., $P$. laruotteanum Cambess. and P. rufum Mart. ex DC.; subtribe Eugeniinae-Eugenia bimarginata O. Berg, E. klotzschiana O. Berg, E. myrcianthes Nied. and E. punicifolia (Kunth) DC.; and subtribe Myrciinae-Myrcia bella Cambess., M. lingua (O. Berg) Mattos, M. multiflora DC., M. splendens DC. and M. tomentosa DC. Voucher specimens of each species were deposited at the Herbarium of the Federal University of São Carlos (accession nos. 8308, 8309, 8319, 8320, 8321, 8322, $8310,8311,8312,8313,8314,8315,8316,8317$ and 8318 , respectively). Leaves were collected and dried in an incubator at $40^{\circ} \mathrm{C}$ for $48 \mathrm{~h}$, then powdered in an electric grinder and stored in plastic containers at room temperature $\left(\approx 25^{\circ} \mathrm{C}\right)$.

The allelopathic effects of these extracts were tested on three target species: two eudicotyledonous species, Lactuca sativa L. (Asteraceae) var. Regina (lettuce) and Solanum lycopersicum L. (Solanaceae) var. IPA 6 (tomato); and the monocotyledonous species Allium cepa L. (Liliaceae) var. Baia Periforme (onion).

\section{Preparation of plant extracts}

The extracts were prepared by mixing powdered dried leaves with distilled water in the proportion $1 \mathrm{~g}$ powder: 10 $\mathrm{ml}$ water, at $10 \%$ weight/volume. This solution was stored at $\approx 5^{\circ} \mathrm{C}$ for $12 \mathrm{~h}$. The extract was then filtered by suction through a Buchner funnel covered with filter paper (Gatti et al. 2010).

\section{Germination bioassay}

The seeds of the target species were placed in Petri dishes $(9 \mathrm{~cm}$ in diameter) lined with two sheets of filter paper moistened with $5 \mathrm{ml}$ of an aqueous leaf extract or with the same volume of distilled water (control). The experiments were carried out with four replicates of 20 seeds per dish for each extract. Petri dishes containing lettuce and tomato seeds were maintained in a biochemical oxygen demand germination chamber at $25^{\circ} \mathrm{C}$ and Petri dishes containing onion seeds were maintained at $20^{\circ} \mathrm{C}$. After preliminary tests performed to determine the optimal germination conditions for each target species, all of the Petri dishes were maintained on a 12/12-h light/dark cycle. Germination counts were made every $12 \mathrm{~h}$ for 15 days. Seeds that sprouted a 2-mm primary root were classified as having germinated (Borghetti \& Ferreira 2004). 


\section{Seedling growth bioassay}

The seeds used in this bioassay were first germinated in water (until presenting a root length of $2-4 \mathrm{~mm}$ ), then moved to transparent plastic boxes $(500 \mathrm{ml}, 14 \times 10 \mathrm{~cm})$ lined with two sheets of filter paper and moistened with $13 \mathrm{ml}$ of extract or distilled water (control). The boxes were kept in biochemical oxygen demand germination chambers, under the same conditions described for the germination bioassay. The length of the shoot and primary roots, in $\mathrm{mm}$, were measured with a digital caliper after seven days.

\section{Physicochemical characteristics of the extracts}

The osmotic potential of the extracts was measured with an osmometer (5004 MICRO-OSMETTE; Precision Syste$\mathrm{ms}$, Natick, MA, USA). Osmolality was measured in mOsm $\mathrm{kg}^{-1}$ and converted to MPa (Larcher 2004). The germination and growth bioassays of lettuce, onion and tomato were carried out with polyethylene glycol (PEG) 6000 solutions in order to simulate the osmotic potential recorded in the extracts. The PEG solution was prepared in accordance with specifications given by Sun (2002), and the germination and growth bioassays followed the method described above.

The $\mathrm{pH}$ of the extracts was measured with a $\mathrm{pHmeter}$ (PM608; Analion, Ribeirao Preto, Brazil). Because the $\mathrm{pH}$ of all the samples was within the range recommended for germination and plant growth (Larcher 2004), bioassays to evaluate the influence of $\mathrm{pH}$ were not carried out.

\section{Mathematical and statistical analysis}

We calculated proportional germination, expressed as a percentage; average germination time, in days; informational entropy of germination, in bits (Ranal \& Santana 2006); and the response index for the allelopathic effect (Zhang et al. 2010). The response index was calculated as follows:

$R I=\left(T . C^{-1}\right)-1$

where $R I$ is the response index, $T$ is the germination rate (seeds germinated per day) for seeds exposed to the leaf extract, and $C$ is the germination rate (seeds germinated per day) for the control seeds.

The design of the laboratory experiments was completely randomized, with four replications for each treatment. The statistical significance of the differences between the treatments and the control were investigated by Student's t-test, for normal data, or by the Wilcoxon test, for non-normal data, both at the $5 \%$ level.

A taxonomic distance matrix of Gower dissimilarity based on genus and subtribe was constructed for the 15 donors. Subsequently, a Euclidean distance matrix of donors was created based on the mean values of each variable (proportional germination, average germination time, informational entropy of germination, shoot length and root length) for all target species. The correlations between donors, in terms of the taxonomic and Euclidean distances, were tested with Mantel's test (Manly 2000). A dendrogram was built from the Euclidean distances, using the group average method, to define the clusters formed by the donor species with similar allelopathic effects. Clusters were identified by a dissimilarity $\geq 50$. We used ANOVA, followed by Tukey's test, in order to illustrate which variables influence the clustering. All statistical analyses were performed with the program R, version 2.9.1 (R Development Core Team 2009).

\section{Results}

The osmotic potential of the aqueous leaf extracts ranged from -0.1 to $-0.2 \mathrm{MPa}$. The bioassays using PEG 6000 showed that the osmotic potential did not influence germinability, average germination time or seedling length (Fig. 1 and 2).

The results obtained in the germination bioassay are shown in Fig. 1. Regarding the first eudicotyledonous species (lettuce), the aqueous leaf extracts of C. pubescens and $P$. cinereum did not have significant effects on the germination rate, although they did significantly increase the average germination time. In addition, lettuce seeds displayed high values for information entropy when subjected to C. pubescens extract, indicating low synchrony of the germination process. Regarding the second eudicotyledonous species (tomato), the aqueous leaf extracts of C. pubescens, E. myrcianthes and P. cinereum did not significantly reduce proportional germination, although they did significantly increase the average germination time. In the monocotyledon species (onion), the effects of the aqueous leaf extracts of E. myrcianthes, E. punicifolia, M. multiflora, M. splendens, $M$. tomentosa and P. laruotteanum had significant effects on the germination rate, and all of the extracts except C. pubescens, E. myrcianthes, P. cinereum and P. laruotteanum, had significant effects on average germination time (Fig. 1). Hence, all of the extracts inhibited the germination of eudicotyledon and monocotyledon seeds, with the exception of the extracts of $C$. pubescens and P. cinereum, which did not inhibit the germination of monocotyledon seeds. All of the target species seeds had a negative response index, indicating the presence of allelopathic activity on the part of all donor species (Fig. 1).

The results of the growth bioassay are shown in Fig. 2. Among the eudicotyledonous species, the extracts inhibited shoot and root growth for lettuce seedlings. Regarding tomato, all of the tested extracts caused significant inhibition of root growth, whereas shoot growth was reduced by 11 of the 15 extracts. In the monocotyledon species (onion), all extracts reduced root growth; however, only eight extracts altered shoot growth.

No correlation was found between the variables of Euclidean and taxonomic distances (Mantel's $r=0.15, p=$ 0.057). Cluster analysis of the allelopathic effects identified four clusters of donor species-clusters A, B, C and D, comprising 1, 5, 4 and 6 species, respectively (Fig. 3). Cluster A 


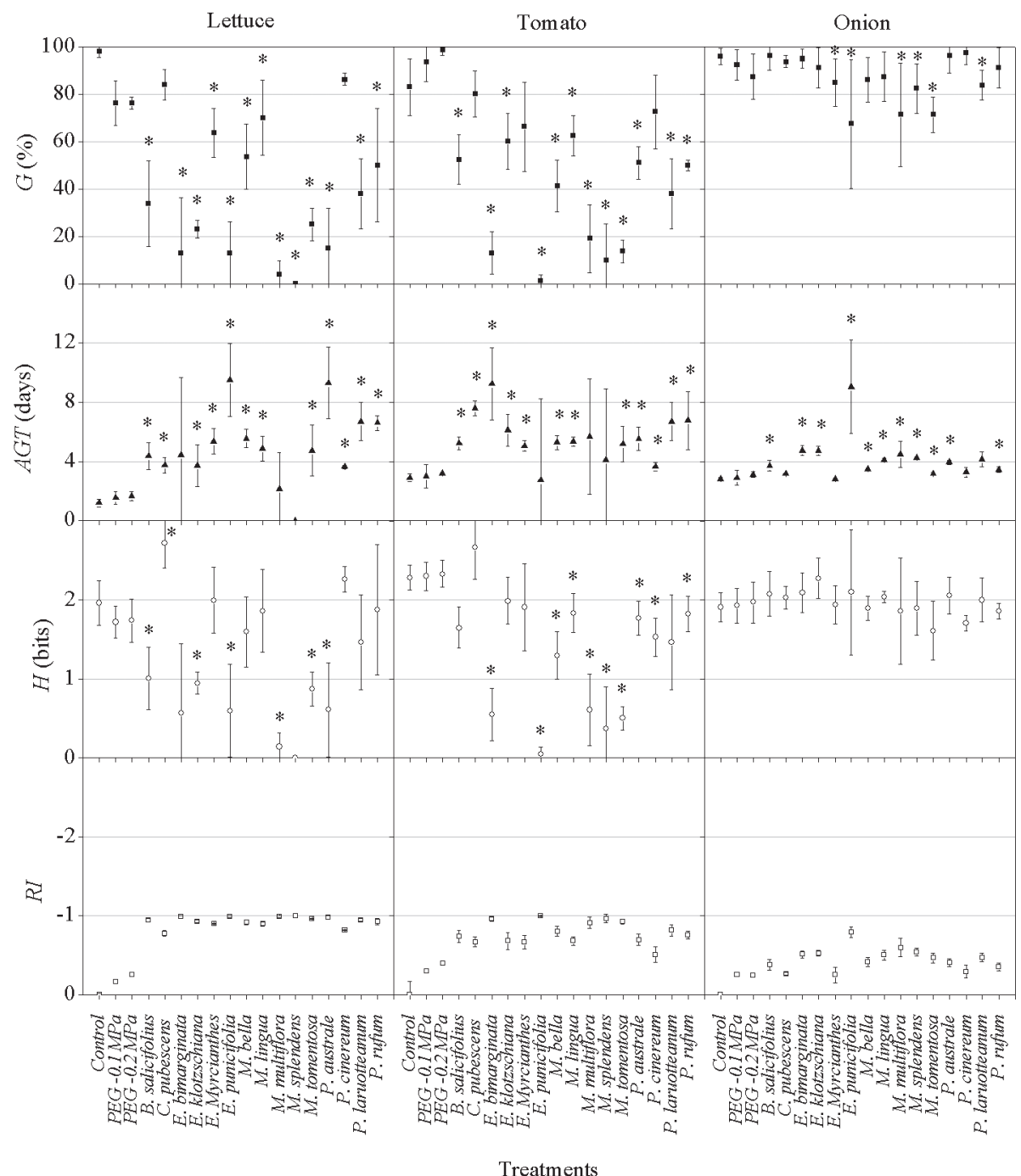

Figure 1. Average values for proportional germination $(G, \mathbf{\bullet})$; average germination time $(A G T, \mathbf{\Lambda})$; informational entropy of germination $(H, O)$ and allelopathic effect, as quantified with a response index $(R I, \square)$, in lettuce, tomato and onion seeds exposed to aqueous leaf extracts of the donor species or to distilled water (control). PEG - polyethylene glycol; B. - Blepharocalyx; C. - Campomanesia; E. - Eugenia; M. - Myrcia; P. - Psidium.

*significantly different from control $(\mathrm{p}<0.05)$.

(control) differed from the other clusters in terms of seed germination for lettuce and tomato; shoot length for onion, tomato and lettuce; and root length for onion and tomato. Cluster C did not differ from cluster A in terms of lettuce seed germination or root length (Table 1 ). In cluster B, the extracts strongly inhibited lettuce and tomato germination, compared with only slight inhibition of such germination in cluster C. Cluster D species extracts moderately inhibited lettuce and tomato germination (Table 1).

\section{Discussion}

The osmotic potentials of the aqueous leaf extracts evaluated significantly influenced neither seed germination nor seedling development (Fig. 1 and 2), indicating that the detrimental effects exerted by the extracts on the germi- nation and growth of the target species resulted from the presence of bioactive substances. According to Grisi et al. (2012), osmotic potentials below $-0.3 \mathrm{MPa}$ do not interfere in seed germination or in the initial growth of seedlings.

The results showed that the monocotyledon and eudicotyledon plants respond differently to the extracts (Fig. 1 and 2). The influence of the extracts on germination depends on the size and permeability of the seed coat (Hanley \& Whiting 2005). The species-dependent response to the allelochemicals shows that they are fundamental not only in natural environments, where they influence floristic composition, but also in agriculture, where they can be used as selective herbicides.

Allelopathic chemicals alter plant growth and seed germination through a multiplicity of effects on physiological and biochemical processes, because there are hundreds of different structures and many of the compounds have 


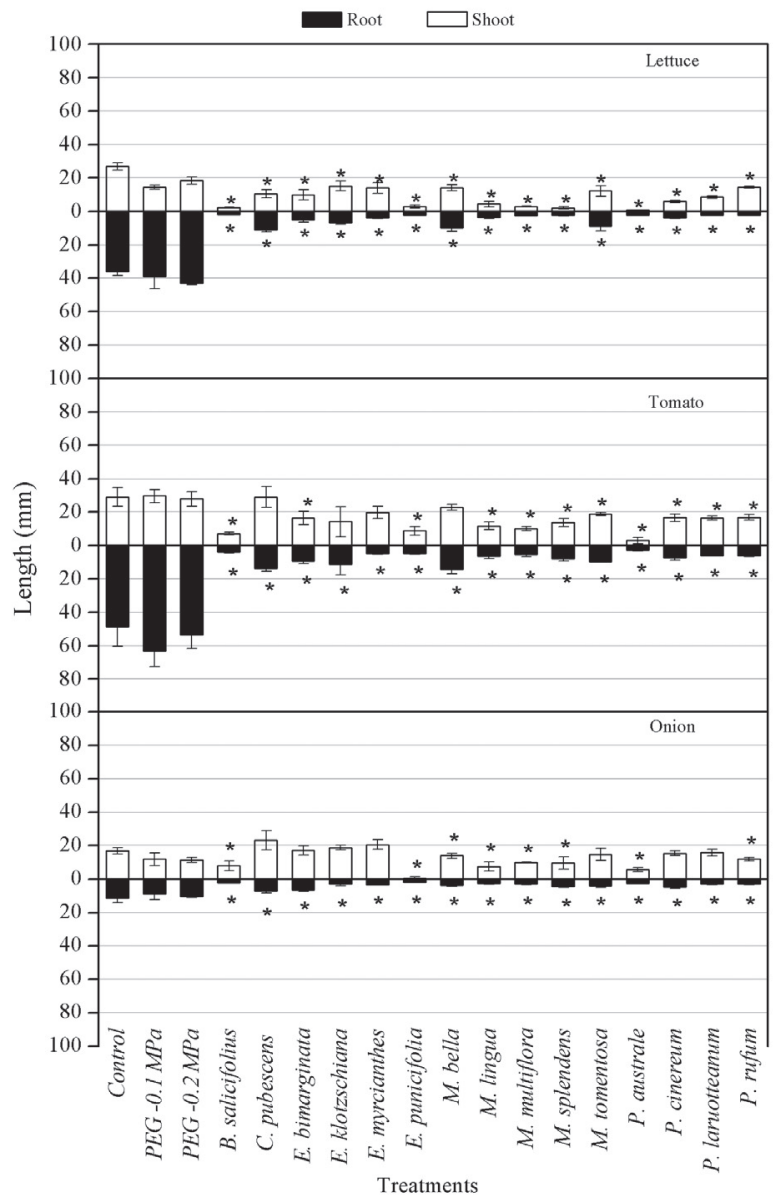

Figure 2. Average lengths of shoots ( $\square$ ) and roots ( $)$ ) of lettuce, onion, and tomato seedlings exposed to aqueous leaf extract of the donor species or to distilled water (control).

PEG - polyethylene glycol; B. - Blepharocalyx; C. - Campomanesia; E. - Eugenia; M. - Myrcia; P. - Psidium.

${ }^{\star}$ significantly different from control $(\mathrm{p}<0.05)$.

multiple phytotoxic effects. According to Singh et al. (2009), phytotoxins can affect enzyme activities or plant hormones, increasing amylase activity and promoting a greater release of reserves that would otherwise be provided to the embryo, extending oxidative stress and seed dormancy through the increase of abscisic acid production and inhibiting water absorption via alterations in membrane permeability. The same author also observed a reduction in protein content and nitrate reductase activity in corn root tissues exposed to Nicotiana plumbaginifolia leachates. Einhellig (1995) also reported that alteration in the enzymatic activity of seeds affects the mobility of stored compounds, thus increasing germination inhibition, or sometimes completely suppressing it. Therefore, the observed differences between the control and treatment groups, in terms of the number of germinated seeds, might be attributed to the presence of allelopathic compounds. The seedling growth results for almost all of the target species showed that the roots were as sensitive to the leaf extracts as were the shoots. Allelochemicals can affect hydrogen adenosine triphosphatase in

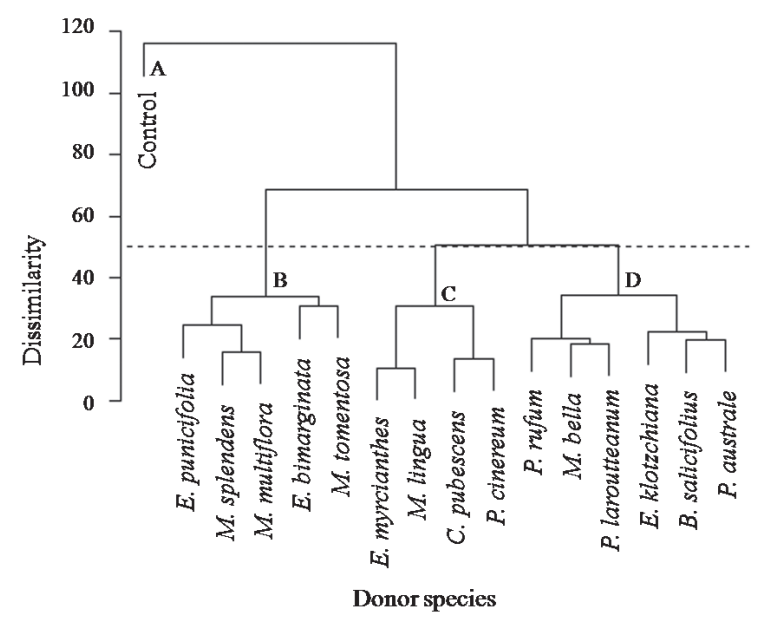

Figure 3. Dendrogram of the allelopathic activity of 15 donor species of the family Myrtaceae. The main clusters were designated at a dissimilarity $\geq 50$. E. - Eugenia; M. - Myrcia; C. - Campomanesia; P. - Psidium; B. - Blepharocalyx.

the plasma membrane, which is responsible for generating the electrochemical proton gradient and thus provides the driving force for the uptake and efflux of ions and metabolites across the plasma membrane. Hydrogen adenosine triphosphatase inhibition results in reduction of the uptake of minerals and water by roots and, consequently, has a significant effect on essential plant functions such as photosynthesis, respiration and protein synthesis, culminating in growth reduction (Gniazdowska \& Bogatek 2005). In addition, allelochemicals have been associated with the inhibition of mitosis and disruption of organelle structure (Zhang et al. 2010), due to their effects on chromatin organization, altering the physical and chemical proprieties of DNA (Teerarak et al. 2012). Cell growth in plants is dependent on the mitotic process. When cell divisions are disturbed during germination, most seedlings either die before emergence or show abnormalities.

The effects of allelochemical activity can be detected at the molecular, structural, biochemical, physiological and ecological levels of plant organization (Gniazdowska \& Bogatek 2005). Allelopathic compounds can induce secondary oxidative stress, manifesting as increased production of reactive oxygen species (ROS), as demonstrated by Weir et al. (2004). It is known that ROS act as signaling molecules, indicating biotic and abiotic stress (Foyer \& Noctor 2005), as well as being major regulators of plant growth and development (Gapper \& Dolan 2006). Certain ROSmainly ethylene and abscisic acid - have been shown to act as second messengers in plant hormone responses (Kwak et al. 2006). Ethylene and abscisic acid are both regarded as common stress hormones involved in the regulation of seed dormancy and germination (Kucera et al. 2005). Some allelochemicals of Artemisia annua have been shown to decrease protein content and increase superoxide dismutase activity (Lixiao et al. 2012). According to Oracz et al. 
Table 1. Allelopathic responses of three target species to the donor species extracts. Clusters of donor species were formed by hierarchical ordering of allelopathic activity. The significance of differences among groups was tested by ANOVA.*

\begin{tabular}{|c|c|c|c|c|c|c|}
\hline Variable & Target & $\begin{array}{l}\text { Cluster A } \\
\qquad(\mathrm{n}=1)\end{array}$ & $\begin{array}{l}\text { Cluster B } \\
\quad(\mathrm{n}=5)\end{array}$ & $\begin{array}{l}\text { Cluster C } \\
\qquad(\mathrm{n}=4)\end{array}$ & $\begin{array}{c}\text { Cluster D } \\
\quad(\mathrm{n}=6)\end{array}$ & $\mathrm{p}$ \\
\hline \multirow{3}{*}{ Germination (\%), mean \pm SD } & Lettuce & $98 \pm 2.3^{\mathrm{a}}$ & $11 \pm 9.7^{c}$ & $76 \pm 10.9^{\mathrm{a}}$ & $35.6 \pm 15.0^{\mathrm{b}}$ & $<0.001$ \\
\hline & Onion & $96 \pm 3.3$ & $77.5 \pm 11.3$ & $90.9 \pm 5.7$ & $90.8 \pm 5.1$ & 0.04 \\
\hline & Tomato & $83 \pm 11.9^{\mathrm{a}}$ & $11.4 \pm 6.5^{\mathrm{d}}$ & $70.3 \pm 7.7^{\mathrm{b}}$ & $48.8 \pm 8.8^{\mathrm{c}}$ & $<0.001$ \\
\hline \multirow{3}{*}{ Average germination time (days), mean $\pm \mathrm{SD}$} & Lettuce & $1.2 \pm 0.3$ & $4.2 \pm 3.6$ & $4.4 \pm 0.8$ & $6.0 \pm 2.0$ & 0.29 \\
\hline & Onion & $2.8 \pm 0.1$ & $5.1 \pm 2.3$ & $3.3 \pm 0.5$ & $3.9 \pm 0.5$ & 0.22 \\
\hline & Tomato & $2.9 \pm 0.3$ & $5.4 \pm 2.4$ & $5.4 \pm 1.6$ & $5.9 \pm 0.7$ & 0.45 \\
\hline \multirow{3}{*}{ Shoot length $(\mathrm{mm})$, mean \pm SD } & Lettuce & $26.5 \pm 2.1$ & $7.0 \pm 6.6$ & $11.4 \pm 2.1$ & $7.3 \pm 4.1$ & 0.01 \\
\hline & Onion & $34.2 \pm 5.1^{\mathrm{a}}$ & $7.5 \pm 5.7^{\mathrm{b}}$ & $11.5 \pm 3.8^{\mathrm{b}}$ & $7.4 \pm 3.1^{\mathrm{b}}$ & $<0.001$ \\
\hline & Tomato & $67.6 \pm 9.1^{\mathrm{a}}$ & $13.7 \pm 5.8^{\mathrm{b}}$ & $15.0 \pm 4.3^{\mathrm{b}}$ & $13.2 \pm 5.1^{\mathrm{b}}$ & $<0.001$ \\
\hline \multirow{3}{*}{ Root length $(\mathrm{mm})$, mean $\pm \mathrm{SD}$} & Lettuce & $27.4 \pm 2.2^{\mathrm{a}}$ & $7.3 \pm 5.8^{\mathrm{b}}$ & $12.1 \pm 5.0^{\mathrm{a}, \mathrm{b}}$ & $9.5 \pm 5.5^{b}$ & 0.03 \\
\hline & Onion & $31.4 \pm 0.9^{\mathrm{a}}$ & $7.6 \pm 4.4^{\mathrm{b}}$ & $12.5 \pm 6.5^{\mathrm{b}}$ & $8.2 \pm 3.8^{\mathrm{b}}$ & 0.004 \\
\hline & Tomato & $63.4 \pm 15.9^{\mathrm{a}}$ & $14.2 \pm 4.6^{\mathrm{b}}$ & $14.5 \pm 4.4^{\mathrm{b}}$ & $12.8 \pm 6.1^{\mathrm{b}}$ & $<0.001$ \\
\hline \multirow{3}{*}{ Entropy (bits), mean \pm SD } & Lettuce & $2 \pm 0.3$ & $0.8 \pm 0.7$ & $1.8 \pm 1.1$ & $1.3 \pm 0.5$ & 0.24 \\
\hline & Onion & $1.9 \pm 0.2$ & $1.9 \pm 0.2$ & $1.9 \pm 0.1$ & $2.0 \pm 0.1$ & 0.6 \\
\hline & Tomato & $2.3 \pm 0.2$ & $0.9 \pm 0.9$ & $1.2 \pm 0.8$ & $1.8 \pm 0.5$ & 0.15 \\
\hline
\end{tabular}

Cluster A - control; Cluster B - Eugenia punicifolia, Myrcia splendens, M. multiflora, E. bimarginata and M. tomentosa; Cluster C - E. myrcianthes, M. lingua, Campomanesia pubescens and Psidium cinereum; Cluster D - P. rufum, M. bella, P. laruotteanum, E. klotzschiana, Blepharocalyx salicifolius and P. australe.

${ }^{*}$ Values on the same row and followed by same superscript letter do not different significantly from each other.

(2012), myrigalone, extracted from Myrica gale, inhibits the seed germination of Lepidium sativum by impeding the metabolism of gibberellins, the metabolism of abscisic acid, and apoplastic superoxide production, all of which are required for endosperm rupture and consequent embryo growth by elongation.

Few studies have focused on the allelopathic potential of Myrtaceae species in Brazil. In a study of sesame and radish (Pina et al. 2009), the leaf extracts of E. dysenterica (Myrtaceae) were found to have no influence on the germination of seeds but drastically reduced the seedling elongation rate. Fresh leaf extracts of Blepharocalyx salicifolius (Myrtaceae) have been shown to reduce the survival and germination of lettuce seeds (Mairesse et al. 2007). Souza-Filho et al. (2006) observed that methanolic and hexane extracts of M. guianensis inhibited seed germination of the weeds Senna obtusifolia and Mimosa pudica. Crushed leaves and aqueous leaf extract of the species Campomanesia adamantium and E. dysenterica, tested in soil, have been found to reduce the length of sesame seedlings (Souza et al. 2007). Species of Eucalyptus - a genus originating mainly from Oceania-have been widely examined for allelopathic potential. Currently, approximately 38 Eucalyptus species of Australia have proven to display inhibitory activity against various organisms (Willis 1999).

The clusters of the donor species investigated in the present study were not aligned by genus or subtribe, as would be expected. This corroborates the results obtained by Santos \& Salatino (2000), who observed the non-clustering of Annonaceae species of the cerrado with respect to the chemical composition of the leaf flavonoids. All donor species studied here belong to the Myrteae tribe, whose systematics have been studied in an attempt to determine the best grouping within the tribe (McVaugh 1968; Salywon et al. 2002; Snow et al. 2003; Wilson et al. 2001; 2005). Wilson et al. (2001) stated that the Myrteae tribe is paraphyletic. Indeed, analysis of the matK gene sequence has demonstrated that the Syzygium/Acmena group arose independently. Lucas et al. (2007) showed that the Myrteae tribe would be monophyletic if the Syzygium/Acmena group were excluded. Among the subtribes studied here, Myrtinae and Eugeniinae are paraphyletic, whereas Myrciinae is monophyletic (Lucas et al. 2005). Studies based on nuclear DNA sequencing suggest that the genus Psidium (subtribe Myrtinae) may be paraphyletic (Salywon et al. 2002), whereas Lucas et al. (2005), using nuclear and plastid DNA sequences, demonstrated that this genus is very likely monophyletic. The genus Blepharocalyx (subtribe Myrtinae) is extremely isolated, and further research is needed in order to establish the relevance of this group within the tribe (Lucas et al. 2005). The genus Eugenia (subtribe Eugeniinae) shows signs of being paraphyletic, furthermore, nuclear and plastid DNA sequence data have demonstrated that the genus Myrcia 
is also paraphyletic (Lucas et al. 2005). Reports in the literature show that most of the investigated genera have a tendency to be paraphyletic, which underscores the results obtained in the present study. Another factor that explains the lack of clustering of the genera studied is the variation in composition and quantity of allelochemicals in the family Myrtaceae. Keszei et al. (2008) stated that the leaves of Myrtaceae species have high concentrations of terpenes and that these compounds show substantial qualitative and quantitative variations between each taxon, population and individual. Other phytochemical studies of Myrtaceae leaves have identified sesquiterpenes, triterpenes, flavonoids and alkaloids in Calycorectes psidiiflorus (Domingues et al. 2010); flavonoids, tannins and phenols in Plinia cauliflora (Souza-Moreira et al. 2010); and flavonoids in Baeckea frutescens (Kamiya \& Satake 2010).

In the present study, which involved eudicotyledonous and monocotyledonous species, germination and growth were both significantly affected by the aqueous leaf extracts evaluated, demonstrating the phytotoxicity of the donor species. This information might foster the success of agricultural and agro-forestry systems, allowing the identification of interspecific associations. In addition, such extracts could be studied from the perspective of their herbicidal, insecticidal and fungicidal properties, which could make them useful in the battle against the main pests responsible for reducing productivity of those systems.

Our data could also be of use in ecological studies, because these species evaluated here can influence the diversity and spatial distribution of individuals in natural communities. On the basis of these results, it is clear that each donor species has a different phytotoxic effect. There was no clustering by genus or subtribe. Therefore, plants from the same environment and with taxonomical proximity showed no similarities in the production of secondary metabolites. For this reason, the hypothesis tested here was rejected; in relation to the production of bioactive compounds, the characteristics intrinsic to each species supersede environmental conditions, as the environment was the same for all species. It was concluded that both the eudicotyledonous and monocotyledonous plants were significantly affected by the presence of aqueous leaf extracts.

\section{Acknowledgements}

This study received financial support from the Brazilian Coordenação de Aperfeiçoamento de Pessoal de Nível Superior (CAPES, Office for the Advancement of Higher Education) and Conselho Nacional de Desenvolvimento Científico e Tecnológico (CNPq, National Council for Scientific and Technological Development; grants to PN and SCJG). We are grateful to D. M. da Silva for assisting in the statistical analyses and to M. Sobral for aiding in species identification.

\section{References}

Abrahim, D.; Braquini, W.L.; Kelmer-Bracht, A.M. \& Ishii-Iwamoto, E.L. 2000. Effects of four monoterpenes on germination, primary root growth, and mitochondrial respiration of maize. Journal of Chemical Ecology 26:611-624.

Ackerly, D.D. 2003. Community assembly, niche conservatism, and adaptive evolution in changing environments. International Journal of Plant Science 164:165-184.

Anaya, A.L. 1999. Allelopathy as a tool in the management of biotic resources in agroecosystems. Critical Reviews in Plant Sciences 18:697-739.

Bogatek, R.; Oracz, K. \& Gniazdowska, A. 2005. Ethylene and ABA production in germinating seeds during allelopathy stress. In Fourth World Congress on Allelopathy. http://www.regional.org.au/au/ allelopathy/2005/2/1/2409_bogatekr.htm. (Accessed 2010 June 22)

Borghetti, F. \& Ferreira, A.G. 2004. Interpretação de resultados de germinação. Pp.209-222. In: Ferreira, A.G. \& Borghetti, F., (Eds.). Germinação: do básico ao aplicado. Porto Alegre, ARTMED.

Cardoso, C.M.V. \& Sajo, M.G. 2006. Nervação foliar em espécies brasileiras de Myrtaceae Adans. Acta Botanica Brasilica 20(3): 657-669.

Domingues, E.A.; Nakamura, C.V.; Souza, M.C.; Teixeira, T.S.; Peixoto, J.L.B.; Sarragiotto, M.H. \& Vidotti, G.J. 2010. Estudo fitoquímico e avaliação da toxicidade frente a Artêmia salina e da atividade antimicrobiana de Calycorectes psidiiforus (O. Berg). Brazilian Journal of Pharmacognosy 20(1):23-27.

Einhellig, F.A. 1995. Mechanism of Action of Allelochemicals in Allelopathy. Pp 96-116. In: ACS Symposium Series. American Chemical Society.

Fang, B.; Yu, S., Wang,; Y., Qiu; X., Cai; C. \& Liu, S. 2009. Allelopathic effects of Eucalyptus urophylla on ten tree species in south China. Agroforest System 76:401-408.

Fine, P.V.A.; Miller, Z.J.; Mesones, I.; Irazuzta, S.; Appel, H.M.; Stevens, M.H.H.; Sääksjärvi, I.; Schultz, J.C. \& Coley, P.D. 2006. The growthdefense trade-off and habitat specialization by plants in Amazonian forests. Ecology 87:150-162.

Foyer, C.H. \& Noctor, G. 2005. Redox homeostasis and antioxidant signaling: A metabolic interface between stress perception and physiological responses. Plant Cell 17:1866-1875.

Fukami, T.; Bezemer, T.M.; Mortimer, S.R. \& Van der Putten, W.H. 2005. Species divergence and trait convergence in experimental plant community assembly. Ecology Letters 8:1283-1290.

Gapper, C. \& Dolan, L. 2006. Control of plant development by reactive oxygen species. Plant Physiology 141: 341-345.

Gatti, A.B.; Ferreira, A.G.; Arduin, M. \& Perez, S.C.G.A. 2010. Allelopathic effects of aqueous extracts of Aristolochia esperanzae O.Kuntze on development of Sesamum indicum L. seedlings. Acta Botanica Brasilica 24(2):454-461.

Gniazdowska, A. \& Bogatek, R. 2005. Allelopathic interactions between plants. Multi site action of allelochemicals. Acta Physiologiae Plantarum 27(3B):395-407.

Grisi, P.U.; Gualtieri, S.C.J.; Ranal, M.A. \& Santana, D.G. 2012. Allelopathic interference of Sapindus saponaria root and mature leaf aqueous extracts on diaspore germination and seedling growth of Lactuca sativa and Allium cepa. Brazilian Journal of Botany 35(1):1-9.

Hanley, M.E. \& Whiting, M.D. 2005. Insecticides and Arable Weeds: Effects on Germination and Seedling Growth. Ecotoxicology 14:483-490.

Haridasan, M. 2008. Nutritional adaptations of native plants of the cerrado biome in acid soils. Brazilian Journal of Plant Physiology 20(3):183-195.

Judd, W.S.; Campbell, C.S.; Kellog, E.A. \& Stevens, P.F. 1999. Plant Systematics. A Phylogenetic Approach. Sinauer Associates Inc., Massachusetts.

Kamiya, K. \& Satake, T. 2010. Chemical constituents of Baeckea frutescens leaves inhibit copper-induced low-density lipoprotein oxidation. Fitoterapia 81:185-189.

Keszei, A.; Brubaker, C.L.; Carte, R., Köllner; T.; Degenhardt, J. \& Foley, W.J. 2008. Functional and evolutionary relationships between terpene synthases from Australian Myrtaceae. Phytochemistry 71: 844-852. 
Kucera, B.; Cohn, M.A. \& Leubner-Metzger G. 2005. Plant hormone interactions during seed dormancy release and germination. Seed Science Research 15: 281-307.

Kwak, J.M.; Nguyen, V. \& Schroeder, J.I. 2006. The role of reactive oxygen species in hormonal responses. Plant Physiology 141: 323-329.

Larcher, W. 2004. Ecofisiologia Vegetal. Rima Artes e Textos, São Carlos.

Lixiao, N.; Kumud, A.; Xiangyang, H. \& Shiyin L. 2012. Isolation and identification of an anti-algal compound from Artemisia annua and mechanisms of inhibitory effect on algae. Chemosphere 88: 1051-1057.

Lucas, E.J.; Belsham, S.R.; Nic Lughadha, E.M.; Orlovich, D.A.; Sakuragui, C.M.; Chase, M.W. \& Wilson, P.G. 2005. Phylogenetic patterns in the fleshy-fruited Myrtaceae - preliminary molecular evidence. Plant Systematics and Evolution 251: 35-51.

Lucas, E.J.; Harris, S.A.; Mazine, F.F.; Belsham, S.R.; Nic Lughadha, E.M.; Telford, A.; Gasson, P.E. \& Chase, M.W. 2007. Suprageneric phylogenetics of Myrteae, the generically richest tribe in Myrtaceae (Myrtales). Taxon 56(4): 1105-1128(24)

Mairesse, L.A.S.; Costa, E.C.; Farias, J.R. \& Fiorin, R.A. 2007. Bioactivity of plant extracts on lettuce (Lactuca sativa L.). Revista da FZVA 14(2): 1-12.

Manly, B.F.J. 2000. Multivariate statistical methods. Chapman and Hall, New York.

Marquis, R.J.; Morais, H.C. \& Diniz, I.R. 2002. Interactions among cerrado plants and their herbivores: unique or typical? Pp.306-328. In: Oliveira, O.S. \& Marquis, R.J., (Eds.). The Cerrados of Brazil. New York, Columbia University Press.

McVaugh, R. 1968. The genus of American Myrtaceae - an interim report. Taxon 17: 354-418.

Monteiro, J.A.F. \& Prado, C.H.B.A. 2006. Apparent carboxylation efficiency and relative stomatal and mesophyll limitations of photosynthesis in an evergreen cerrado species during water stress. Photosynthetica 44: 39-45.

Núñez-Farfán, J.; Fornoni, J. \& Valverde, P.L. 2007. The evolution of resistance and tolerance to herbivores. Annual Review of Ecology, Evolution and Systematics 38: 541-566.

Oliveros-Bastidas, A.J. 2008. El fenómeno alelopático. El concepto, las estrategias de estudio y su aplicación en la búsqueda de herbicidas naturales. Química Viva 7(1): 1-34.

Oracz, K.; Voegele, A.; Tarkowska, D.; Jacquemoud, D.; Turecková, V.; Urbanová, T; Strnad ,M.; Sliwinska, E. \& Leubner-Metzger, G. 2012. Myrigalone a inhibits Lepidium sativum seed germination by interference with gibberellin metabolism and apoplastic superoxide production required for embryo extension growth and endosperm rupture. Plant and Cell Physiology 53(1): 81-95.

Pina, G.O.; Borghetti, F.; Silveira, C.E.S. \& Pereira, L.A.R. 2009. Effects of Eugenia dysenterica leaf extracts on the growth of sesame and radish. Allelopathy Journal 23: 313-322.

R Development Core Team. 2009. R: a language and environment for statistical computing. Version 2.10.1. R Foundation for Statistical Computing, Vienna.

Ranal, M.A. \& Santana, D.G. 2006. How and why to measure the germination process? Revista Brasileira de Botânica 29(1): 1-11.

Ribeiro, J.F. \& Walter, B.M.T. 1998. Fitofisionomias do Bioma Cerrado. Pp.89-166. In: Sano, S.M. \& Almeida, S.P., (Eds.). Cerrado: Ambiente e Flora. Planaltina, EMBRAPA.

Rizvi, S.J.H.; Haque, H.; Sing, V.K. \& Rizvi, V. 1992. A discipline called allelopathy. Pp.1-10. In: Rizvi, S.J.H. \& Rizvi, V., (Eds.). Allelopathy. Basic and applied aspects. London, Chapman and Hall Editors.
Salywon, A.; Snow, N. \& Landrum, L.R. 2002. Phylogenetic relationships of the berry fruited Myrtaceae as inferred from ITS sequences. In: Botany Conference, University of Wisconsin, Madison, Wisconsin. http://2002.botanyconference.org/section12/abstracts/239. shtml. (Accessed 2010 June 22)

Santos, D.Y.A.C \& Salatino, M.L.F. 2000. Foliar flavonoids of Annonaceae from Brazil: taxonomic significance. Phytochemistry 55: 567-573.

Scrivanti, L.R.; Zunino, M.P. \& Zygadlo, J.A. 2003. Tagetes minuta and Schinus areia essential oils as allelopathic agents. Biochemical Systematics and Ecology 31: 563-572.

Singh, A.; Singh, D. \& Singh, N.B. 2009. Allelochemical stress produced by aqueous leachate of Nicotiana plumbaginifolia Viv. Plant Growth Regulation 58: 163-171.

Snow, N.; Guymer, G.P. \& Sawvel, G. 2003. Systematics of Austromyrtus, Lenwebbia, and the Australian species of Gossia (Myrtaceae). Systematic Botany Monographs 65: 1-95.

Souza, L.M.; Canini, G.B.; Aires, S.S. \& Borghetti, F. 2007. Efeito alelopático de folhas de quatro espécies do cerrado sobre crescimento de gergelim. Revista Brasileira de Biociências 5(2): 540-542.

Souza-Filho, A.P.S.; Santos, R.A.; Santos, L.S.; Guilhon, G.M.P.; Santos, A.S.; Arruda, M.S.P.; Muller, A.H. \& Arruda, A.C. 2006. Allelopathic potential of Myrcia guianensis. Planta Daninha 24(4): 649-656.

Souza-Moreira, T.M.; Moreira, R.R.D.; Sacramento, L.V.S. \& Pietro, R.C.L.R. 2010. Histochemical, phytochemical and biological screening of Plinia cauliflora (DC.) Kausel, Myrtaceae, leaves. Revista Brasileira de Farmacognosia 20(1): 48-53.

Sun, W.Q. 2002. Methods for the study of water relations under desiccation stress. Pp.47-92. In: Black, M. \& Pritchard, H.W. (Eds.). Desiccation and survival in plants: drying without dying. London, CABI publishing,

Teerarak, M.; Charoenying, P. \& Laosinwattana, C. 2012. Physiological and cellular mechanisms of natural herbicideresource from Aglaia odorata Lour. on bioassay plants. Acta Physiologiae Plantarum 34: 1277-1285

Teerarak, M.; Laosinwattana, C. \& Charoenying, P. 2010. Evaluation of allelopathic, decomposition and cytogenetic activities of Jasminum officinale L. f. var. grandiflorum (L.) Kob. on bioassay plants. Bioresource Technology 101: 5677-5684.

Watson, L. \& Dallwitz, M.J. 2007. The families of flowering plants: descriptions, illustrations, identification, and information retrieval. http:// delta-intkey.com. (Accessed 2010 June 28).

Webb, C.O.; Ackerly, D.D.; McPeek, M.A. \& Donoghue, M.J. 2002. Phylogenies and community ecology. Annual Review of Ecology, Evolution and Systematics 33: 475-505

Weir, T.; Park, S.W. \& Vivianco, J.M. 2004. Biochemical and physiological mechanisms mediated by allelochemicals. Current Opinion in Plant Biology 7: 472-479.

Willis, R. 1999. Australian studies on allelopathy in Eucalyptus: a review. Pp.201-219. In: Inderjit, Dakshini, K.M.M. \& Foy, C.L., (Eds.). Principles and practices in plant ecology: allelochemical interactions. Florida, CRC Press.

Wilson, P.G.; O’Brien, M.M.; Gadek, P.A. \& Quinn, C.J. 2001. Myrtaceae revisited: a reassessment of infrafamilial groups. American Journal of Botany 88: 2013-2025.

Wilson, P.G.; O’Brien, M.M.; Heslewood, M.M. \& Quinn, C.J. 2005. Relationships within Myrtaceae sensu lato based on a matK phylogeny. Plant Systematics and Evolution 251: 3-19.

Zhang, Y.; Gu, M.; Shi, K.; Zhou, Y.H. \& Yu, J.Q. 2010. Effects of aqueous root extracts and hydrophobic root exudates of cucumber (Cucumis sativus L.) on nuclei DNA content and expression of cell cycle-related genes in cucumber radicles. Plant Soil 327: 455-463. 